\title{
非交差型鋼構造柱梁接合部の構造性能に関する研究 EXPERIMENTAL STUDY ON THE STRUCTURAL PERFORMANCE OF NON-INTERSECTION TYPE STEEL BEAM-TO-COLUMN CONNECTION
}

\author{
山田 哲*1, 吉江 慶 祐*2, 向 野聡彦*3, 小島大輔*4 \\ Satoshi YAMADA, Keisuke YOSHIE, Toshihiko KOUNO \\ and Daisuke KOJIMA
}

\begin{abstract}
Non intersection-type beam-to-column connection of steel moment resisting frame is proposed. This connection is composed of rectangular hollow section column, wide flange section beam and rectangular hollow section bracket. In this connection, moment is transmitted from beam to column by torsion moment of bracket. In order to evaluate the structural performances of non intersection type beam-to-column connection, a series of experimental and analytical study is carried out. From both of experimental and analytical results, it is clarified that non intersection type connection behave stable even in the plastic region.
\end{abstract}

Keywords: Steel Structure, Beam-to-Column Connection, Experiment, FEM 鋼構造, 柱梁接合部, 実験, FEM

\section{1. 序}

近年、意匠性と構造性を合理的に融合させた建築が増えてきてい る。本研究で扱う接合部も意匠性との融合を目指した構造システム の一つであり、図 1 に示すように、箱形断面部材からなる柱の芯と $\mathrm{H}$ 形断面部材からなる大梁の芯を大きくずらして、ねじれに強い閉断 面部材からなるブラケットを介して接合するものである。この接合 部は、柱を外壁面および外周大梁芯から外側にオフセットさせるこ とで彫りの深い外観を持たせると当時に、室内側には柱型をださな いすっきりとした内部空間を実現することを意図したものである。 この接合部形式をこれ以降「非交差型柱梁接合部」と呼ぶ。各部位 の名称を図 1 に示す。ここで、柱から離れた位置にある梁と接続す るための閉断面部材をブラケット、柱側の接合部パネルゾーンを柱 パネル、梁側の接合部パネルゾーンを梁パネルと呼ぶ。また、柱の ブラケット上下フランジが接続する位置には、梁からのモーメント を伝えるためのダイアフラムを設けている。

鋼構造建築におけるこのような接合方式は米国に実施例を見るこ とができるが ゆ、地震力などの水平外力を受けた場合には柱芯と梁 芯が離れていることによって柱に大きなねじりモーメントが作用す る。地震が多発する我が国において非交差型の接合形式を採用する には、柱はねじれに強い閉断面とする必要がある。このような接合 形式は実績が少なく、実用化のためには基䃈資料の蓄積が必要であ る。なお、梁が柱に対して偏心して接合されることは一般的な鋼構 造建築においても外壁を取り付ける外周構面などで行われることが
多く、これまでも偏心接合部の性能に関する研究も行われており 2) 5症と㸚じりモーメントがパネルに作用するせん断力へ与える影響 などが検討されているが、非交差型柱梁接合部では梁から柱へブラ ケットを介して応力伝達を行う点や、柱と梁で合計 3 枚のパネルが 存在する点など、一般的な柱梁偏心接合部と大きく異なる特徵を有 していることから、新たな検討が必要である。本研究では、柱を箱 形断面部材とした非交差型柱梁接合部を対象に、実大に近い規模で のト型ならびに十字型の部分骨組試験体に対する繰り返し載荷実験 と非線形有限要素法解析を行い、特に塑性化後も安定した変形性能 が発揮できるかという点に着目して構造性能の検証を行った。

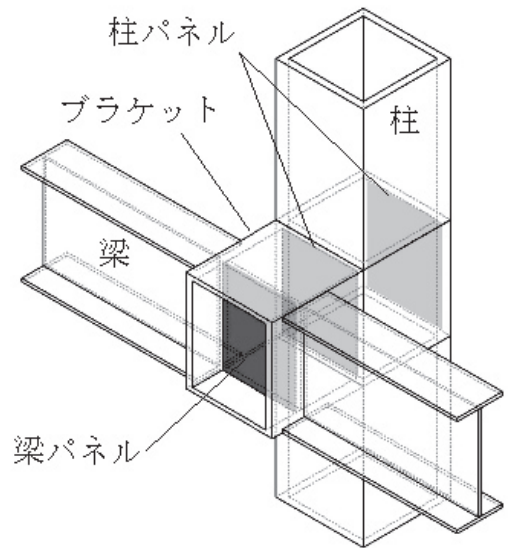

図1 接合部の概要と各部位の名称

\footnotetext{
*1 東京工業大学建築物理研究センター 准教授 · 博士 (工学)

Assoc. Prof., Structural Engineering Research Center, Tokyo Institute of Technology,

*2 日建設計構造設計室 主管·博士 (工学)

*3 日建設計構造設計室 室長·工修 Dr. Eng.

Structural Engineering Dept., Nikken Sekkei LTD., Dr. Eng.

Structural Engineering Dept., Nikken Sekkei LTD., M. Eng.

*4 元 東京工業大学大学院 大学院生·修士(工学)

Former Graduate Student, Tokyo Institute of Technology, M. Eng.
} 


\section{2. 接合部におけるカの流れと剛性・耐力の評価式}

\section{1水平外力下におけるカの流れの概要}

水平外力を受ける連続ラーメン架構内の接合部について、作用す る外力と力の流れの概要を図 2 に示す。実際の建物ではこのほかに 鉛直荷重も作用しているが、本研究では非交差型接合部における耐 震性能の評価、中でも崩壊メカニズムに関わる構成要素の全塑性耐 力の評価を中心に基本的な検討を行うこととし、接合部に作用する 荷重としては水平外力のみを考慮する。

一般的な梁接合部では梁端部に作用した曲げモーメントとせん断 カはパネルゾーンを介して柱に伝わる。この接合部でも応力は梁パ ネルと柱パネルを介して梁から柱に伝わるが、梁パネルと柱パネル の間にブラケットが存在する点が異なる。ブラケットは、ダイアフ ラムと柱スキンプレート同様、パネルゾーンの枠材として機能する と同時に、梁から柱への応力を伝達する要素として機能する。水平 外力によって梁端に生じる曲げモーメントは、ブラケットにはねじ りモーメントとして作用し柱に伝わる点が非交差型接合部の特徴と なっている。また、柱に作用するねじりモーメントは一般的な偏心 接合においても問題となるが、非交差型接合部では柱心と梁心が大 きくずれていることから、極めて大きな㸚じりモーメントが柱に作 用する点も特徵である。柱に作用するねじりモーメントは、当該層 に作用する水平外力によって柱に作用するせん断力を $\Delta Q_{i}$ 、柱芯と 梁芯間の距離を $e_{i}$ とすると、 ${ }_{e} M=\sum_{j=i}^{N} \Delta Q_{j} \cdot e_{j}(N$ は建物の層数 $)$ と表さ れ、柱を伝わり柱脚まで流れる。

\section{2ブラケット}

梁と柱を繋ぐブラケットには、梁からの曲げモーメントが䄱じり モーメント ${ }_{b} M$ として作用寸る。叔じりモーメントを受けるブラケ ットの変形状態を図 3 に示す。ここで梁パネルと柱パネルに生じる せん断変形はブラケットの衫じれ変形に影響しないものとし、ブラ ケットが薄肉管であると仮定する。ねじりモーメント $M_{t}$ が作用する 薄肉管に生じるせん断応力度は

$$
\tau=\frac{M_{t}}{2 \cdot A \cdot t}
$$

ここで、 $A$ : 薄肉管の板厚中心線で囲まれる面積、 $t:$ 薄肉 管の板厚

で表される の社苂。さらに薄肉管の板厚が一定の場合、単位長さあ たりに生じる㸚じり角は

$$
\theta=\frac{M_{t} \cdot s}{4 \cdot A^{2} \cdot t \cdot G}
$$

ここで、 $s$ :薄肉管の板厚中心線の全長、 $G$ :せん断弾性係数

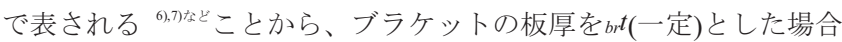
には、ねじりモーメント ${ }_{b r} M$ によって生じるせん断応力度 $b_{r} r$ と回転 角 $b_{1} \theta$ は式(3)、(4)で表される。

$$
\begin{aligned}
& { }_{b r} \pi=\frac{{ }_{b r} M}{2 \cdot b \cdot h \cdot b_{r} t} \\
& { }_{b r} \theta=\frac{{ }_{b r} M \cdot 2 \cdot(b+h)}{4 \cdot(b \cdot h)^{2} \cdot{ }_{b r} t \cdot G} \cdot d=\frac{b_{r} M \cdot(b+h) \cdot d}{2 \cdot b^{2} \cdot h^{2} \cdot{ }_{b r} t \cdot G} \\
& \text { ここで、 } b \text { :柱フランジの板厚中心間距離、 } h \text { :梁フランジの }
\end{aligned}
$$

板厚中心間距離、 $d$ :ブラケット長さ(梁側柱パネル板厚中 心と梁パネル板厚中心間の距離)

この他に水平外力によって柱に作用するせん断力の増分 $\Delta Q$ がブラ ケットを介して柱に伝わるが、ブラケットの上下で $1 / 2$ ずつ柱に伝 達され、ブラケットのねじれ剛性や全塑性耐力には影響しないもの と仮定すると、ねじりモーメントに対するブラケットの弾性剛性 ${ }_{b r} K 、$ 全塑性耐力 ${ }_{b r} M_{p}$ は式(5)、(6)で表される。

$$
\begin{aligned}
& { }_{b r} K=\frac{{ }_{b r} M}{{ }_{b r} \theta}=\frac{2 \cdot b^{2} \cdot h^{2} \cdot b_{r} t \cdot G}{(b+h) \cdot d} \\
& { }_{b r} M_{p}=2 \cdot b \cdot h \cdot b_{b r} t \cdot b_{r} \tau_{y} \\
& \text { ここで、 }{ }_{b r} \tau_{y}: \text { ブラケット材のせん断降伏応力度 }
\end{aligned}
$$

\section{3パネル}

梁と柱の 3 枚のパネルの負担せん断力を求める。接合部を図 4 に 示すように、パネル上端で切断して考える。ここで左右の梁から作 用する曲げモーメント ${ }_{b} M_{L} 、{ }_{b} M_{R}$ はフランジ中央に作用寸る力に偶力 置換して表す。なお、水平外力によって柱に作用するせん断力の増 分 $\Delta Q$ によって生じる柱のねじりモーメント $\mathrm{k} M$ については、パネル にはせん断力として作用しないことからここでは考慮していない。

分割したモデルの上部に注目すると、外力としては梁からのモー メントの置換偶力 $\left({ }_{b} M_{L}+{ }_{b} M_{R}\right) / h$ と水平外力によって柱に作用するせ 几断力の増分 $0.5 \Delta Q$ 、柱からのせん断力 $Q_{u}$ が作用する。これに対す る接合部の反力は、梁パネルのせん断力 ${ }_{p} Q$ と、内側(梁側) と外側の 2 枚の柱パネルのせん断力 ${ }_{c p i} Q 、{ }_{c p o} Q$ である。ここで、梁からの曲げ によってブラケットに生じる応力は前項で述べたねじりモーメント によって生じるせん断応力度吹であり、ブラケット上面においては これに断面積を掛けて求まるせん断力と水平外力によって柱に作用 するせん断力の増分の和

$$
{ }_{b r} Q_{u}={ }_{b r} \tau \cdot b \cdot b_{b r} t-0.5 \Delta Q={ }_{b r} M / 2 h-0.5 \Delta Q
$$

がせん断力として伝わる。

図 5 に示寸ようにブラケット側柱フェイスで切断して考えると、 梁側における $\mathrm{x}$ 方向の力の釣り合いから、梁パネルに作用するせん 断力は

$$
\begin{aligned}
{ }_{b p} Q & =\left({ }_{b} M_{L}+{ }_{b} M_{R}\right) h-0.5 \Delta Q-{ }_{b r} Q_{u} \\
& =\left({ }_{b} M_{L}+{ }_{b} M_{R}\right) h-b r M / 2 h
\end{aligned}
$$

と求まる。一方柱側について、 $\mathrm{x}$ 方向の力の釣り合いと柱側パネル 位置におけるモーメントの釣り合いは

$$
\begin{aligned}
& { }_{b r} Q_{u^{-} c} Q_{u^{\prime}-c p i} Q-c p o \\
& Q^{\prime} \cdot b-{ }_{c} Q_{u} \cdot b / 2-{ }_{c p o} Q \cdot b=0
\end{aligned}
$$

となる。ここで、柱断面に $\mathrm{y}$ 方向に作用寸るせん断力 $Q^{\prime}$ は、ブラケ ットから伝わるねじりモーメント ${ }_{b} M$ 秝、柱断面の図心から $b / 2$ 偏心 した位置に $b_{r} Q_{u}$ として作用寸ることによって柱断面内に生じるねじ りモーメントによるものであるので、柱を薄肉管と仮定することで 式(1)よりこのねじりモーメントにより生ずるせん断応力度が

$$
\begin{aligned}
& \tau=\frac{{ }_{b r} Q_{u} \cdot b / 2}{2 \cdot b^{2} \cdot{ }_{c} t}=\frac{{ }_{b r} Q_{u}}{4 \cdot b \cdot{ }_{c} t} \\
& \text { ここで、 }{ }^{c} t \text { :柱の板厚 }
\end{aligned}
$$

であることから、これに断面積 $b \cdot c t$ を掛けて 
<smiles>[3H]C([3H])I</smiles>

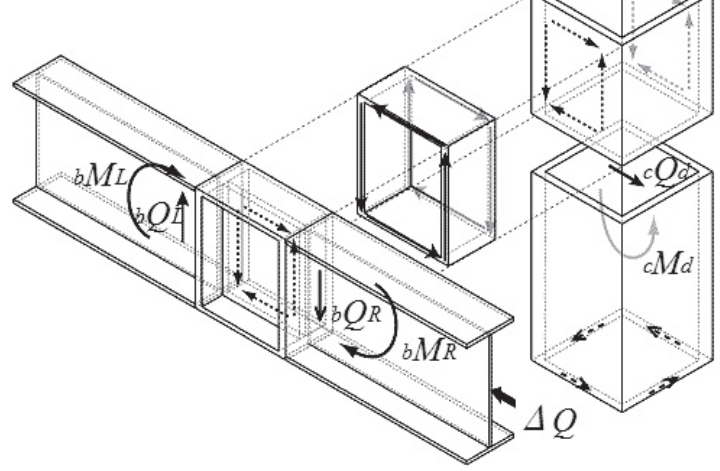

図2 接合部に作用する外力と力の流れの概要

$$
Q^{\prime}=\frac{{ }_{r} Q_{u}}{4}
$$

と求められる。式(9)、(10)、(12)から、内側(梁側)と外側の 2 枚の 柱パネルに作用するせん断力は、それぞれ

$$
\begin{aligned}
& { }_{c p i} Q=\frac{3}{4}{ }_{b r} Q_{u}-\frac{1}{2}{ }_{c} Q_{u} \\
& { }_{c p o} Q=\frac{1}{4}{ }_{b r} Q_{u}-\frac{1}{2}{ }^{c} Q_{u}
\end{aligned}
$$

と求められる。梁と柱内側(梁側)、柱外側の各パネルに作用するせ ん断力をパネルモーメントで表すと、それぞれ

$$
\begin{aligned}
& { }_{b p} M={ }_{b} M_{L}+{ }_{b} M_{R^{-} b r} M / 2 \\
& { }_{c p i} M=\frac{3}{8}{ }_{b r} M-\left(\frac{1}{2}{ }_{c} Q_{u}+\frac{3}{8} \Delta Q\right) \cdot h \\
& { }_{c p o} M=\frac{1}{8}{ }_{b r} M-\left(\frac{1}{2}{ }_{c} Q_{u}+\frac{1}{8} \Delta Q\right) \cdot h
\end{aligned}
$$

となる。また、弾性剛性と全塑性モーメントは板厚を $p t$ 、せん断降 伏応力度を $p \tau_{y}$ とすると

$$
\begin{aligned}
& { }_{p} K=b \cdot h \cdot{ }_{p} t \cdot G \\
& { }_{p} M_{p}=b \cdot h \cdot{ }_{p} t \cdot{ }_{p} \tau_{y}
\end{aligned}
$$

となる。

\section{3. 部分骨組の繰り返し載荷実験と有限要素法解析}

\section{1 実験および解析の目的}

前章において説明した、柱を箱形断面部材とした非交差型柱梁接 合部における力の流れと耐力・剛性の評価式を検証するため、接合 部周辺を抽出したト型ならびに十字型の部分骨組試験体に対する繰 り返し載荷実験を行った。また、実験では複雑な形状を有する試験 体の局所変形を正確かつ詳細に計測することが困難であったことか ら、実験結果を補完するために有限要素法解析を行った。

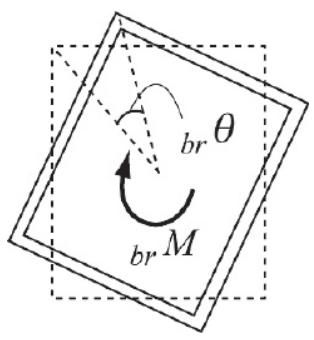

図3 ブラケットの回転

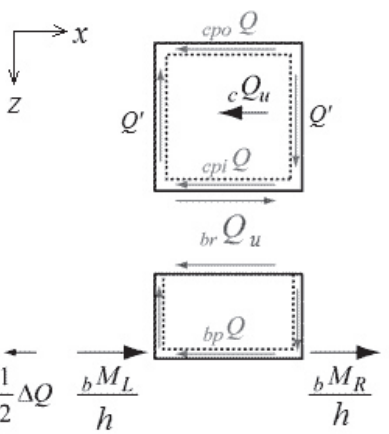

図5 切断面に作用する力

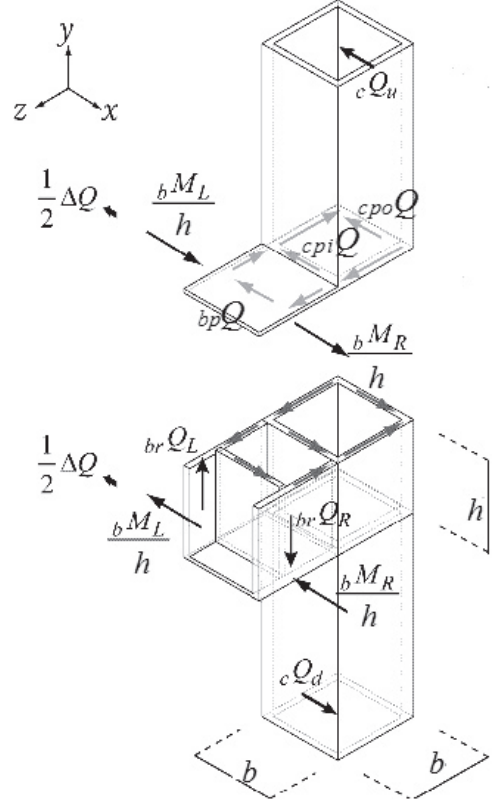

図4 パネル上部での切断

\section{2 実験の概要}

実験は 2 期に分けて行った。試験体は表 1 に示寸第 1 期(下型)4 体、第 2 期(十字型) 2 体の計 6 体を用意した。試験体の形状を図 6 に示す。第 1 期は、溶接組み立ての施工試験も兼ねたため、載荷フ レームに収まる範囲でなるだけ大きな試験体とし、ト型の試験体と した。溶接は $\mathrm{CO}_{2}$ 半自動溶接により行い、ブラケットと柱の溶接、 梁パネルとブラケットの溶接、内ダイアフラムの溶接、梁フランジ とブラケットの溶接など、重要な応力伝達箇所の溶接は完全溶け込 み溶接とした。第 2 期の実験では、一般的な応力状態について検討 するため、寸法がやや小さい十字型の試験体とした。第 1 期の卜型 試験体は高さ $30 \mathrm{~m}$ 程度の事務所ビルを想定すればほぼ実大、第 2 期の十字試験体は $2 / 3$ 程度の縮尺率に相当する。

試験体の一覧を表 1 に、JIS-1A 号引張試験片による素材試験結 果の一覧を表 2 示す。表 1 中には、素材試験結果を用いて計算した 各要素の全塑性耐力と、これを梁端が全塑性耐力に達する時点に各 要素に作用するモーメントで除した各要素の梁に対する相対的な耐 力(梁に対する耐力比)を示している。卜型の試験体シリーズにおい ては、Tp-1.0 が標準試験体となっており梁がブラケット・パネルに 先行して全塑性耐力に到達寸る。これに対して、Tp-1.5 は梁パネル を約 1.5 倍に強くした試験体、Tp-0.5 は梁パネルを約 0.5 倍に弱く した試験体であり、Tp-0.5 では梁パネルがほぼ梁と同時に全塑性耐 力に到達する。また、Tbr-1.0 は梁パネルを強く、ブラケットを弱 くした試験体であり、ブラケットの塑性化も予測される。一方十字 型の試験体は、ブラケットの耐力がパラメーターとなっているが、 いずれもブラケットが梁・パネルに先行して全塑性耐力に到達す る。なお、第 1 期の卜型試験体においては柱と柱パネルは弾性範囲 に留まると予想し、柱の両側にブラケットを出して 2 体の試験体で 柱を共有するようにした。 


\section{3 載荷方法}

載荷装置を図 7 に示す。第 1 期の実験では柱を横に寝かせ梁を縦 にし、梁の先端に油圧ジャッキを取り付けて、載荷点位置の水平変 位で制御して繰り返し載荷を行った。なお、柱端部の上下変位及び 回転は PC 鋼棒により載荷フレームに拘束し、水平変位については

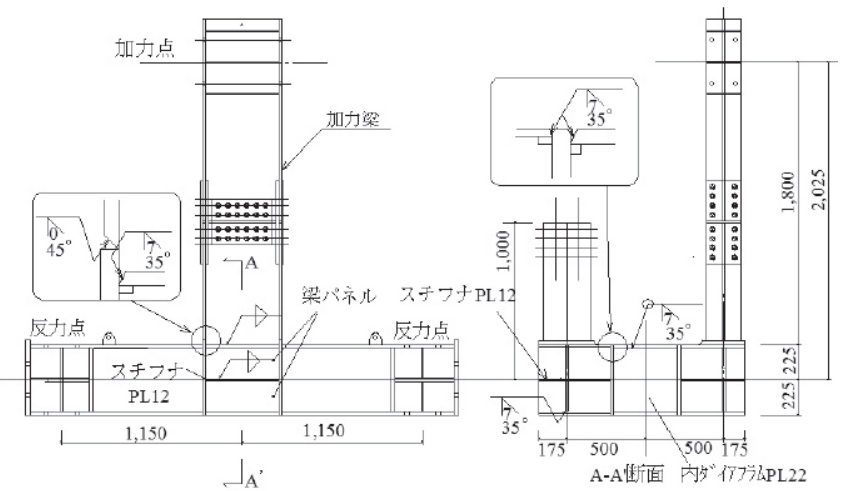

(1) 卜型試験体(第 1 期)

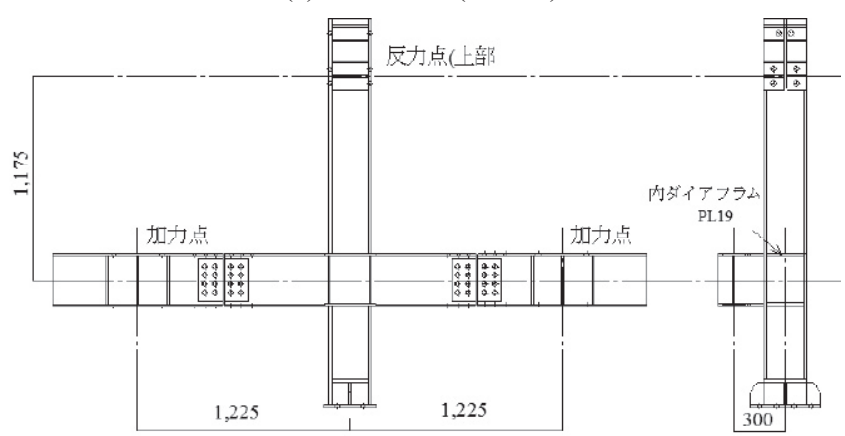

(2) 十字型試験体(第 2 期)

図6 試験体形状

表2素材試験結果

\begin{tabular}{|c|c|c|c|c|c|c|}
\hline & & 鋼種 & $\begin{array}{c}\text { 実測板厚 } \\
(\mathrm{mm})\end{array}$ & $\begin{array}{c}\text { 降伏点 } \\
\left(\mathrm{N} / \mathrm{mm}^{2}\right) \\
\end{array}$ & $\begin{array}{l}\text { 引張強さ } \\
\left(\mathrm{N} / \mathrm{mm}^{2}\right)\end{array}$ & $\begin{array}{c}\text { 破断伸び } \\
(\%) \\
\end{array}$ \\
\hline \multirow{6}{*}{$\begin{array}{l}\text { 第 } 1 \text { 期 } \\
\text { (卜型) }\end{array}$} & PL-6 & SN400B & \begin{tabular}{|l|}
6.03 \\
\end{tabular} & \begin{tabular}{|l|}
348 \\
\end{tabular} & 482 & 23.3 \\
\hline & PL-9 & SN400B & 9.12 & 299 & 453 & 29.6 \\
\hline & PL-12 & $\mathrm{SN} 400 \mathrm{~B}$ & 12.07 & 307 & 440 & 31.1 \\
\hline & PL-16 & SN400B & 16.00 & 281 & 426 & 31.8 \\
\hline & PL-19 & SN400B & 19.20 & 285 & 436 & 32.4 \\
\hline & PL-22 & SN400B & 22.13 & 261 & 417 & 35.5 \\
\hline \multirow{5}{*}{$\begin{array}{l}\text { 第2期 } \\
\text { (十字) }\end{array}$} & PL-6 & SN400B & 5.87 & 285 & 451 & 30.7 \\
\hline & PL-9 & SN400B & 9.07 & 315 & 460 & 30.6 \\
\hline & PL-12 & SN400B & 12.27 & 278 & 451 & 30.7 \\
\hline & PL-16 & SN400B & 15.95 & 265 & 404 & 34.1 \\
\hline & PL-19 & SN400B & 19.10 & 285 & 440 & 32.7 \\
\hline
\end{tabular}

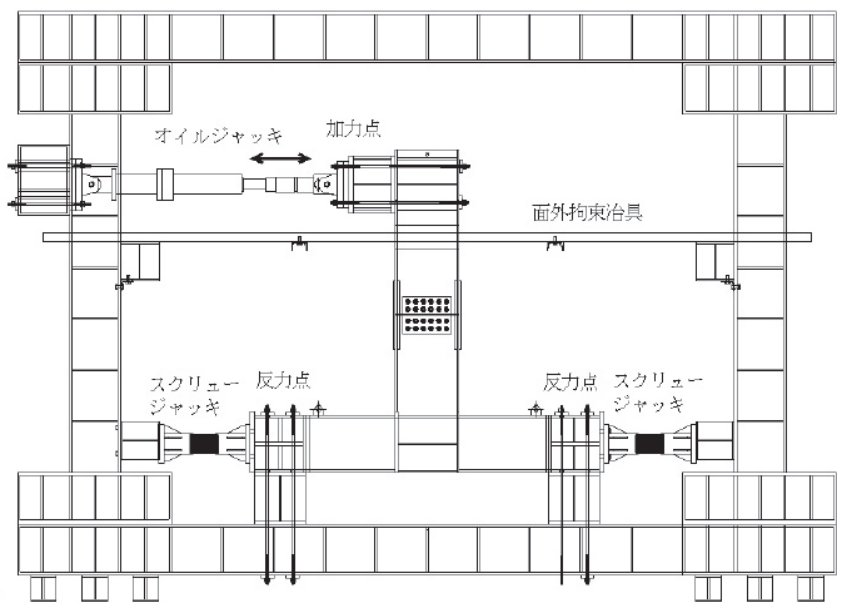

(1) ト型試験体(第 1 期)セットアップ

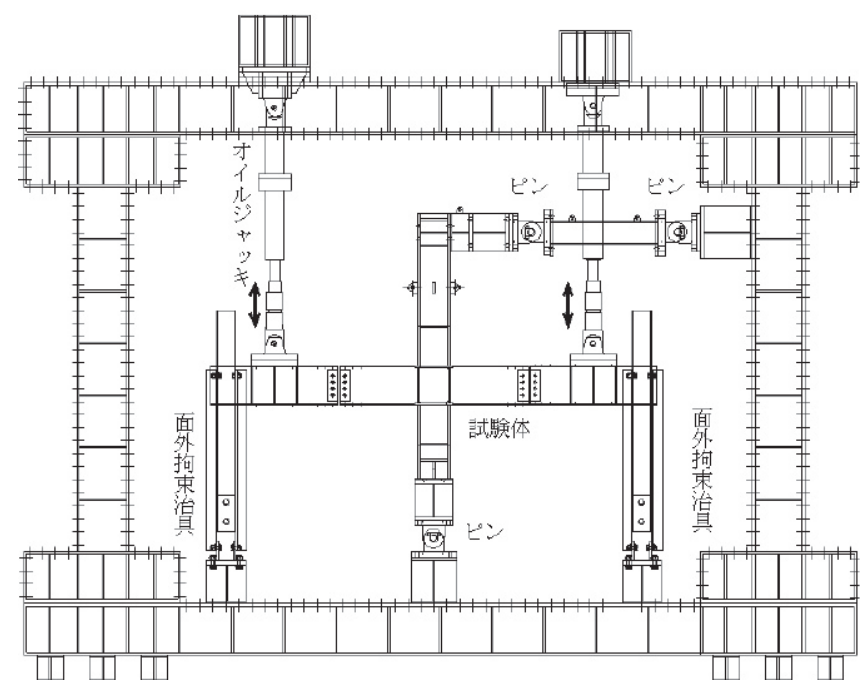

(2) 十字型試験体 (第2期) セットアップ

図7 載荷装置
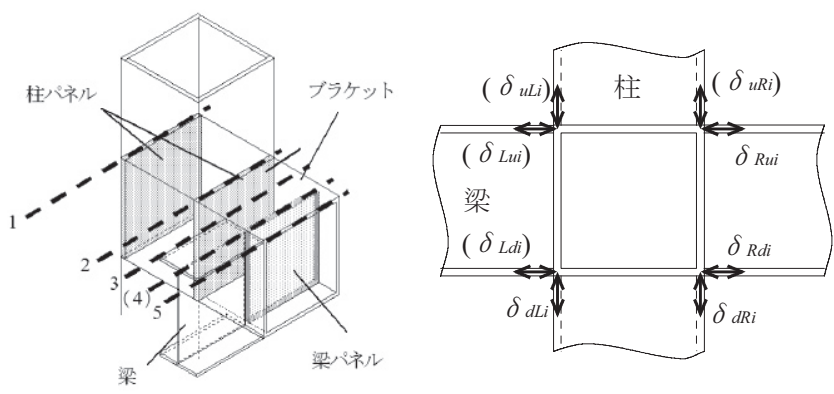

図8 計測を行った断面

図9 変位計測位置

表1 試験体一覧

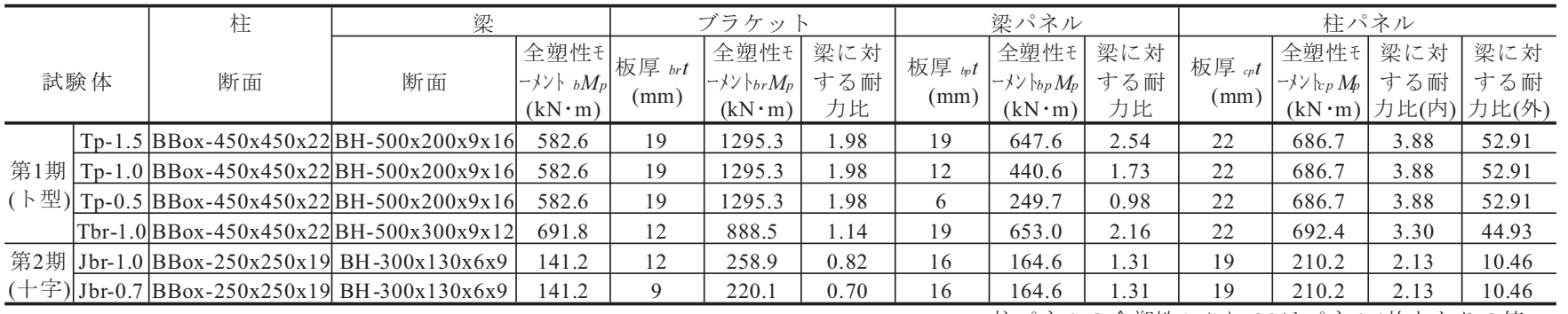


載荷フレームとの間にスクリュージャッキをかませることで拘束し た。柱に添付した歪ゲージによるモーメント分布の計測から、反力 点はほぼピンと見なせると判断した。また、梁の載荷位置付近をチ ヤンネル材で挟み面外変形を抑えたが、接合部近傍での面外変形は 拘束しなかった。一方、第 2 期の実験においては、柱の上端をピン ローラー支持、下端をピン支持とし、梁の先端に油圧ジャッキを取 り付け、載荷点位置における鉛直変位で制御して逆対称繰り返し載 荷を行った。面外変形に対する補剛は梁の載荷位置付近のみとし、 接合部近傍の面外変形は自由とした。また、柱両端のピンは並列に 2 つずつ使用し、上下端における回転を拘束した。

載荷履歴は、文献 8)に示されている接合部実験での標準的な載 荷履歴を準用し、弾性範囲で 1 回繰り返し載荷を行った後、基準変 位 $\delta_{s}$ に対して変位振幅増分を $2 \delta_{s}$ として、載荷点位置における鉛直変 位が各振幅で 2 回ずつとなる繰り返す漸増変位振幅を基本とした。 $\delta_{s}$ は、第 1 期、第 2 期とも $10 \mathrm{~mm}$ としたが、これは $\mathrm{Tp}-1.5 、 \mathrm{Jbr}-1.0$ 試験体について、まず梁を片持ち梁と考えたときの全塑性モーメン 卜に対する弾性変形量を計算し、これに接合部で生じるであろう変 形を想定して割り増したうえで、きりのよい数字とした染意的な值 である。なお、Tp-1.0については梁の横補剛が不十分であったため、 梁の面外変形が大きくなり途中で載荷を終了した。また、Jbr-1.0 については片側のジャッキに不具合が発生したため、途中から載荷 履歴が乱れている。

\section{4 計測}

図 8 に示す接合部の 5 断面及び載荷位置の変位を計測し、これら 変位計測值から変形を算定した。各断面における計測位置における 変位は、図 9 に示寸ように $\mathrm{i}$ 断面において

$\delta_{u L i}$ : 左上隅の上下変位、 $\delta_{L u i}$ : 左上隅の水平変位

$\delta_{d L i}$ : 左下隅の上下変位、 $\delta_{L d i}:$ 左下隅の水平変位

$\delta_{u R i}$ : 右上隅の上下変位、 $\delta_{R u i}$ : 右上隅の水平変位

$\delta_{d R i}$ : 右下隅の上下変位、 $\delta_{R d i}$ : 右下隅の水平変位

である。図 $8 、 9$ で括弧書きした計測項目は、十字型試験体のみ計 測した項目である。これらの変位から各断面に対して、上下面の回 転角 $\theta_{u i} 、 \theta_{d i}$ と左右側面の回転角 $\theta_{L i} 、 \theta_{R i}$ を式 $(20) \sim(23)$ により算出寸 る。これらの回転角から、式(24)により各断面のせん断変形角 $x_{i}$ を 算出寸る。柱パネルのせん断変形角は $c_{p} Y_{i}=\gamma_{i}(\mathrm{i}=1,2)$ であり、梁パネ

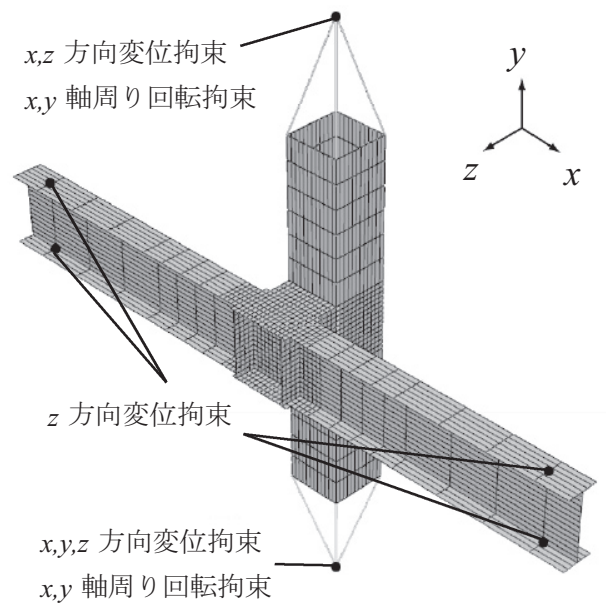

図10 有限要素法解析のモデル

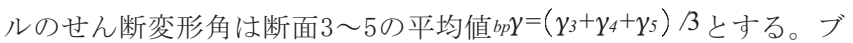
ラケットについては、ブラケットが取り付く断面 2 の柱面から断面 $3 \sim 5$ までの相対回転角b $\theta_{i}$ を、式( 25$)$ により算出する。また、梁パネ ルについては4カ所に3軸ゲージを添付し、せん断歪を計測した。

$$
\begin{aligned}
& \theta_{u i}=\left(\delta_{u L i}-\delta_{u R i}\right) / l \\
& \theta_{d i}=\left(\delta_{d L i}-\delta_{d R i}\right) / l \\
& \theta_{L i}=\left(\delta_{L u i}-\delta_{L d i}\right) / l \\
& \theta_{R i}=\left(\delta_{R u i}-\delta_{R d i}\right) / l \\
& y_{i}=\left(\theta_{u i}+\theta_{d i}-\theta_{L i}-\theta_{R i}\right) / 2 \\
& \text { ここで、i は断面番号、lは計測点間距離 } \\
& { }_{b r} \theta_{i}=\frac{\theta_{u i}+\theta_{d i}+\theta_{L i}+\theta_{R i}}{4}-\frac{\theta_{u 2}+\theta_{d 2}+\theta_{L 2}+\theta_{R 2}}{4}
\end{aligned}
$$

\section{5 解析の概要}

実験を補完するため、汎用有限要素法プログラム ABAQUS を用 いた弾塑性解析を行った。解析モデルを図 10 に示す。解析モデル は、板幅方向に分割の無いシェル要素で作成し、ブラケット、パネ ル、梁端部の応力が大きくなる箇所については $20 \mathrm{~mm}$ 角以下の四 角形要素で分割した。境界条件については、柱端部の断面及びその 頂点と支持点を結ぶ 4 つの線材を 2 次元剛体要素とし、上下端の点 をそれぞれピンローラー支持、ピン支持とした。また、固有值解析 により得られた 1 次モードの座屈波形を用いて、最大で板厚の $2 \%$ となる初期不整を導入し、変位制御法により板要素の座屈劣化も考 慮した解析を行った。材料特性としては素材試験結果を用い、降伏 条件はVon Misesの降伏条件とした。

\section{4. 実験結果と解析結果 \\ 4.1 全体挙動}

試験体の荷重一変形関係を、図 11 に示寸部分骨組の柱に作用す るせん断力 $Q_{f r}$ と全体変形角 $\theta_{f r}$ の関係で表し図 12 に示寸。図中には 実験結果を実線で、FEM による解析結果を灰色の太線で、同一断 面の柱と梁の軸芯を一致させて通常の接合とした場合の弾性剛性と 全塑性耐力の計算值を破線で示している。弾性剛性の計算にあたっ ては、柱と梁は曲げ変形とせん断変形を考慮した。また、全塑性耐 力は、柱、梁、パネルゾーンの中で最も低い梁の塑性化によって決 まる耐力である。

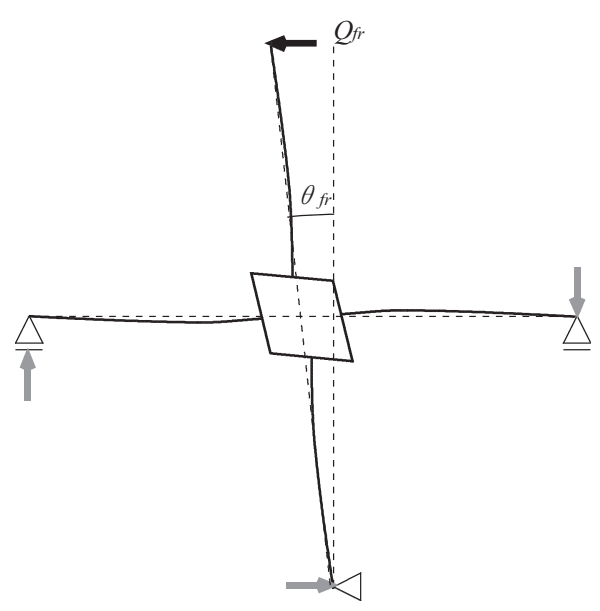

図11 部分骨組の変形状態 
実験結果と解析結果は剛性、耐力のいずれも良く対応しており、 塑性域においても全体的に安定した挙動を示している。卜型の試験 体では相対的に弱い梁が塑性化した後に局部座屈が梁に発生して最 大耐力に至った。その中で、比較的梁パネルを弱くした $\mathrm{Tp}-0.5$ で は梁パネルが、比較的ブラケットを弱くした Tbr-1.0 ではブラケッ トが塑性化したが、後述するようにいずれも安定した履歴挙動を示 した。一方ブラケットを弱くした十字試験体では、ブラケットが先 行して塑性化したことで梁の損傷が抑えられた。いずれの試験体に おいても溶接箇所には有害な割れは発生せず、破断による耐力低下 は起こしていない。

弾性剛性については、柱と梁の軸芯を大きくはずしたことで通常 の接合部とした場合に比べ変形要素が増えていることにより、低下 してする。今回用いた試験体について、第 1 サイクル正側での除荷 剛性を通常の接合部とした場合の弾性剛性の計算値と比較すると、 約 70\%〜 60\%となっている。

\section{2 ブラケットの挙動}

各試験体のブラケットに作用したねじりモーメント ${ }_{b r} M$ と回転角 bəの関係を図 13 に示す。図中には実験結果を実線で、FEMによる 解析結果を灰色の太線で、式(5)、(6)による弾性剛性 $b_{K} K$ と全塑性耐 力 ${ }_{b} M_{p}$ の計算值を破線で示している。

まず耐力であるが、ブラケットを梁やパネルに対して相対的に弱 くした Jbr-1.0、Jbr-0.7 および比較的ブラケットの弱い Tbr-1.0 では、 ブラケットは塑性化を伴う安定した履歴挙動を示しており、実験結 果における耐力も解析結果や式(4)による全塑性耐力の計算值と対 応している。また、ブラケットを強くした試験体 Tp-1.5、Tp-1.0、 $\mathrm{Tp}-0.5$ でも実験結果には非線形性がみられ、中でも梁パネルの弱い Tp-0.5 では比較的早期に塑性化したような挙動を示しているが、こ れらは梁パネルのせん断変形に伴うブラケットの変形を計測してし まったものと考えられる。なお、FEMによる解析結果においては、 ブラケットは弾性に留まっている。
一方弾性剛性であるが、比較的試験体のサイズが大きかった卜型 の試験体については、実験結果と解析結果はいずれも式(5)による 計算結果と良い対応を示している。試験体のサイズが小さかった十 字型の試験体 Jbr-1.0、Jbr-0.7 については、解析結果は計算值と対 応しているが、実験結果との対応は悪い。これも計測誤差によるも のと考えられる。

\section{3 パネルの挙動}

各試験体の梁パネルに作用したパネルモーメント ${ }_{b p} M$ とせん断変 形角 $b_{p}$ \%の関係を図 14 に示す。図中には実験結果を実線で、FEM に よる解析結果を灰色の太線で、式(18)、(19)による梁パネルの弾性 剛性と全塑性耐力の計算值 ${ }_{p} K 、{ }_{b} M_{p}$ を破線で示している。実験結 果におけるせん断変形角は、前述のように変位計による計測におい て誤差が大きかったと考えられることから、貼付した 4 枚の 3 軸ゲ ージによるせん断歪の平均值を以てせん断変形角の実験值とした。

いずれの試験体においても弾性剛性は実験、解析は計算值と良い 対応を示している。耐力については、梁パネルに対してブラケット が十分強くかつ梁パネルが塑性化する $\mathrm{Tp}-0.5$ では実験結果と解析 結果はいずれも全塑性耐力の計算值と良い対応を示しているが、梁 パネルに対してブラケットが弱い Jbr-1.0 と Jbr-0.7 では、実験結果 と解析結果のいずれも全塑性耐力の計算值より低い荷重で梁パネル が塑性化している。これは、枠組材でもあるブラケットが塑性化し たことにより、梁パネルが早期に塑性化したものと考えられる。

柱パネルについてはいずれの試験体でも弾性に留まっていたこと から、Tp-1.5 試験体で代表し、柱内側(梁側)と柱外側の各パネルに それぞれ作用するパネルモーメント $c p i M 、 c p o M$ とせん断変形角 $c p i$ 、 ${ }_{c} p 0 Y$ の関係で図 15 に示寸。図中には FEM による解析結果を灰色の 太線で、式(18)、(19)による柱パネルの弾性剛性と全塑性耐力の計算 值 ${ }_{c} K 、{ }_{c p} M_{p}$ を破線で示している。特に外側の柱パネルに作用するモ ーメントは、式(16)、(17)からもわかるように、偏心の影響で小さ くなっている。
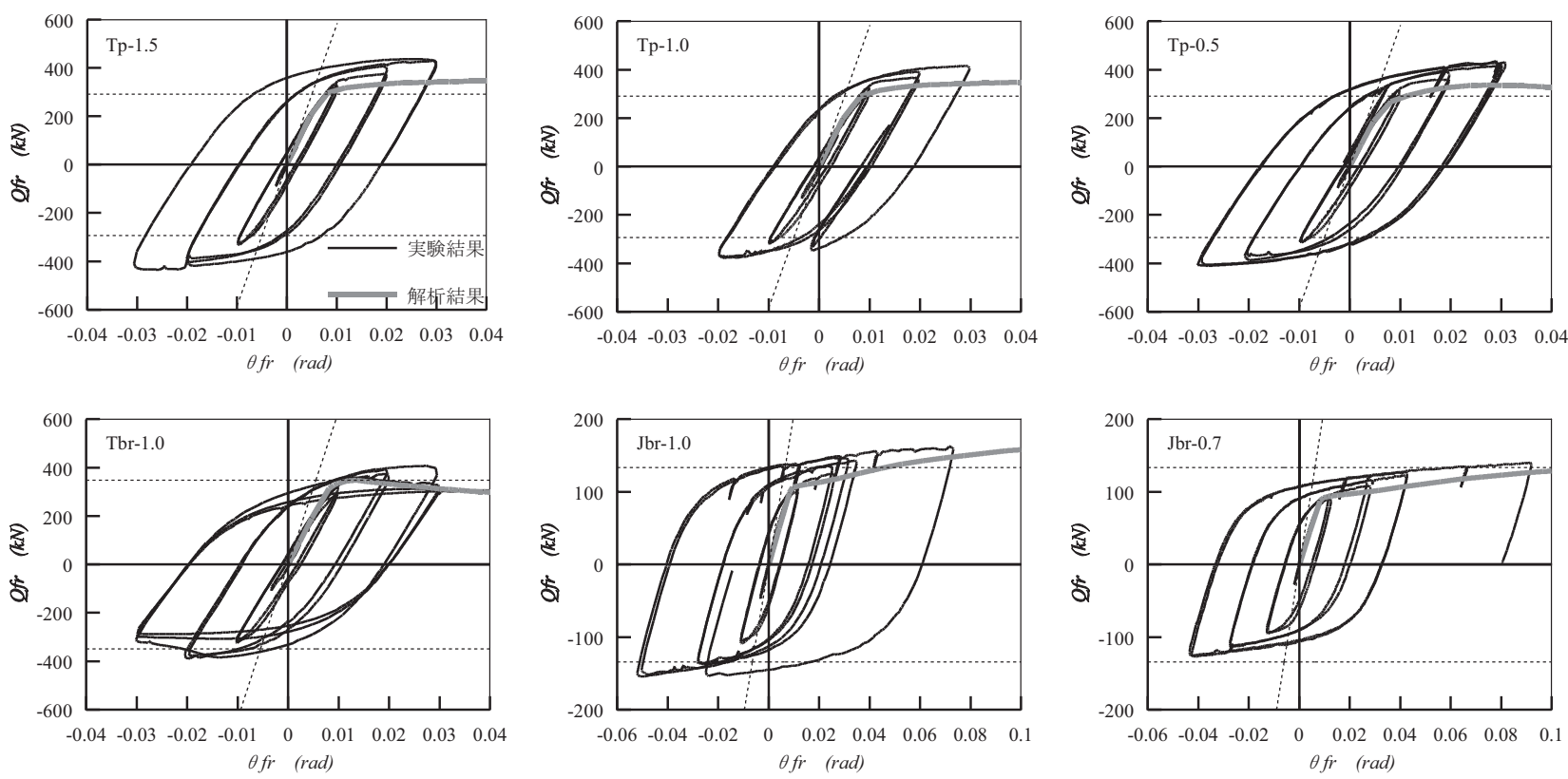

図12 試験体の荷重-変形関係 (全体挙動) 

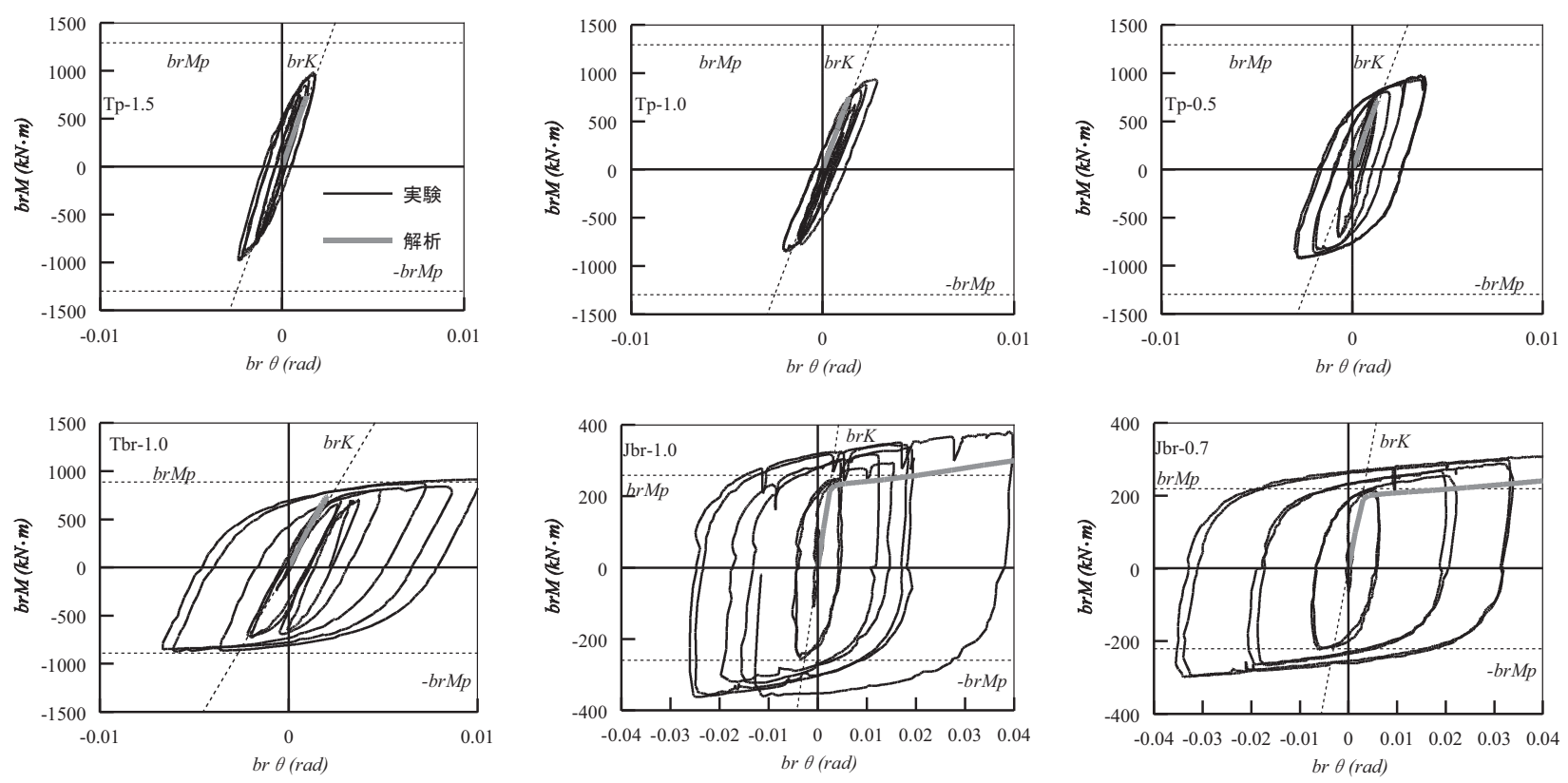

図13 ブラケットの荷重-変形関係
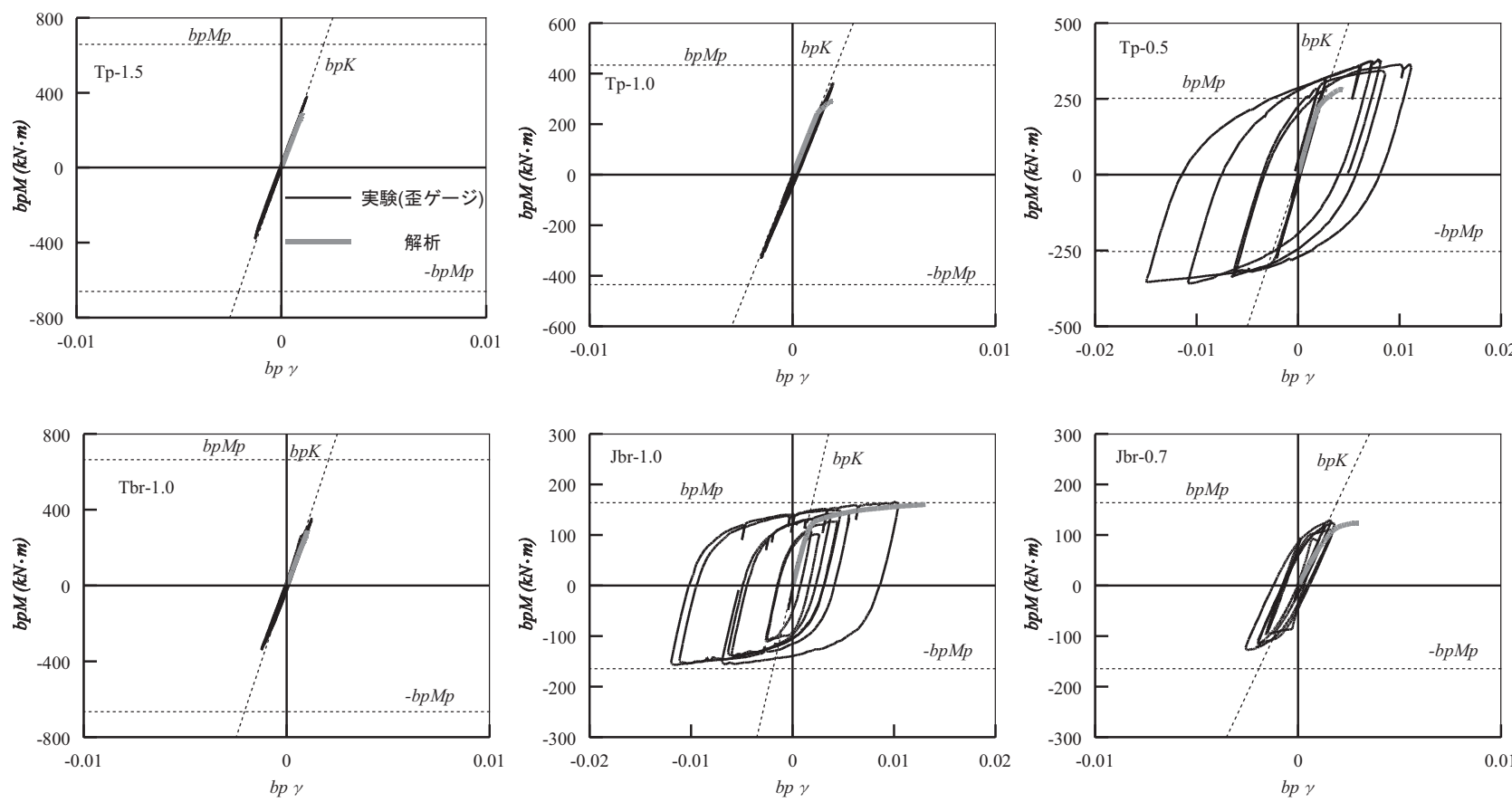

図14 梁パネルの荷重-変形関係
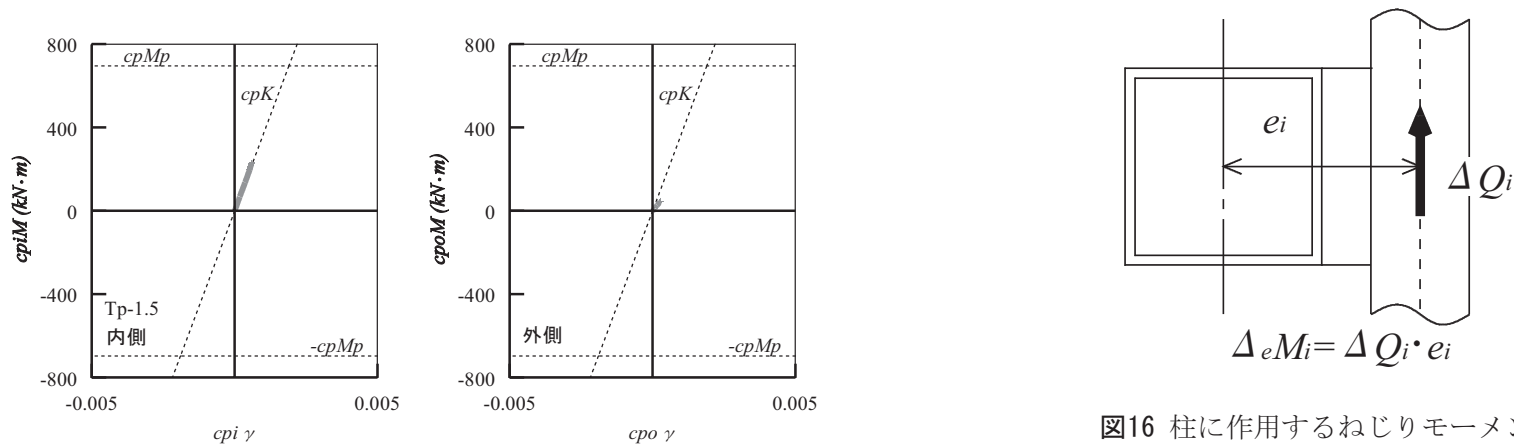

図16 柱に作用するねじりモーメント

図15 パネルの荷重-変形関係 


\section{5. 柱が受けるねじりモーメントに対する検討}

4 章では接合部周辺を抽出した部分骨組を対象とした実験ならび に解析により、非交差型柱梁接合部の接合部性能を検証し、塑性域 においても安定した挙動を示すことを明らかにした。非交差型柱梁 接合部を建物に適用するためには、接合部性能に対する検討だけで なく、水平外力を受ける際には柱芯と梁芯がずれていることによっ て柱に数じりモーメントが作用することから、この影響についても 検討しておく必要がある。

柱 1 本あたりに各層に作用する水平外力によって作用するせん断 力の増分を $\Delta Q_{i}$ 、柱芯と梁芯間の距離を $e_{i}$ とすると、図 16 に示すよ うに、層ごとに $\Delta_{e} M_{i}=\Delta Q_{i} \cdot e_{i}$ のねじりモーメントが柱に作用寸る。 高さ方向に梁芯が揃っており偏心距離 $e_{i}$ が一定 $\left(e_{i}=e\right)$ である場合、あ る層の柱にはそれより上の層の接合部から作用するねじりモーメン トの総和

$$
\begin{aligned}
& { }_{e} M_{i}=\sum_{j=i}^{N} \Delta Q_{j} \cdot e=Q_{i} \cdot e \\
& \text { ここで } Q_{i} \text { は当該柱に作用する層せん断力 }
\end{aligned}
$$

が作用する。水平力によって当該柱に作用する曲げモーメントは、 柱の長さ(内法寸法)をdとし反曲点位置を材長中央と仮定すると、 ${ }_{c} M_{i}=Q_{i} \cdot{ }_{c} l / 2$ であることから、非交差型の接合形式とした場合には、 柱には材端に作用する曲げモーメントの $l / 2 e$ の大ささねじりモー メントが作用することになる。柱断面を $\square-500 \times 500 \times 25$ 、柱の長さ を $c=3000 \mathrm{~mm}$ とした場合の、材端部において断面に作用する曲げ応 力度 $b \sigma$ に対するねじりモーメントによるせん断応力度 $t$ の比率を、 偏心距離eとの関係で表し図 17 に示す。この場合、柱断面幅程度の 偏心距離 $(e=500 \mathrm{~mm}$ 程度)であれば、ねじりモーメントによるせん断 応力度は曲げ応力度の $20 \%$ 程度であり、軸力比にもよるが曲げ耐 力が 1 割程度低下寸る。

また、基礎部のみでねじりモーメントに対する反力をとる場合に は、柱脚部ごとに $e_{e} M_{l}=Q_{l} \cdot d / 2\left(Q_{l}\right.$ は各柱がそれぞれ 1 層において負 担する層せん断力)のねじりモーメントを処理する必要がある。

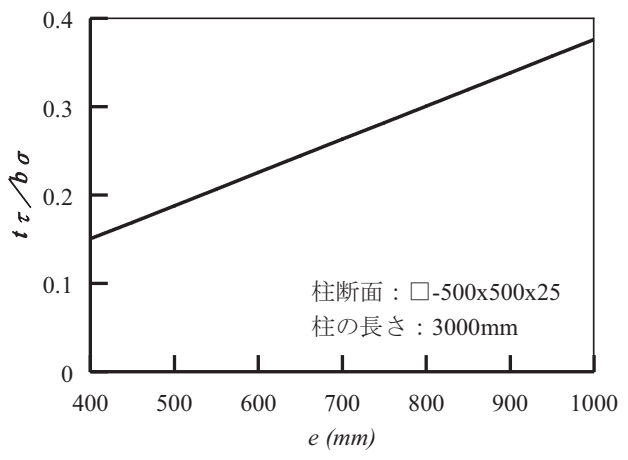

図17 柱断面に作用するせん断応力度と曲げ応力度の比率と 偏心距離の関係

\section{6. 結}

箱形断面部材からなる柱の芯と $\mathrm{H}$ 形断面部材からなる大梁の芯 を大きくずらして、ねじれに強い閉断面部材からなるブラケットを 介して接合する非交差型柱梁接合部について、力の流れと接合要素 の耐力・剛性の評価法を示すとともに、ト型ならびに十字型の部分 骨組試験体を対象とした繰り返し載荷実験と有限要素法解析を行 い、接合部の構造性能を検討した。

1.非交差型柱梁接合部では、接合部を構成する要素のうち梁、梁パ ネル、ブラケットのいずれかを塑性化させる設計を行うことになる。 部分骨組の実験・解析から、ブラケットの塑性化を先行させた場合 には、ブラケットが枠組材となっている梁パネルが計算上の耐力よ りも低い荷重で塑性化することが観察されたが、いずれの部位を塑 性化させた場合も安定した履歴挙動を示すことを確認した。 2.接合部を構成するブラケット、梁パネルおよび 2 枚の柱パネルの 剛性・耐力は、ブラケットの塑性化を先行させた場合の梁パネルの 耐力を除き、本論文で示した計算式により評価できる。

3.非交差型柱梁接合部を採用した場合、骨組の弾性剛性は低下寸る。 本論文で検討した試験体の場合、通常の接合部とした場合の約 $70 \%$ 〜 60\%となった。

4.非交差型柱梁接合部を採用した場合、柱には水平外力下において ねじりモーメントが作用する。個々の柱に対してねじりモーメント に対する反力をとることと、ねじりモーメントの影響による曲げ耐 力の低下に対する検討が必要である。

\section{謝辞}

本研究における実験は、元東京工業大学大学院生飯田佳貴君の修 士課程における研究として行ったものである。実験計画の立案、結 果の検討にあたって、日建設計構造設計室小崎 均氏、小野潤一郎 氏、染谷朝幸氏、貞許美和氏から数々の助言をいただいた。実験の 実施にあたっては、元東京工業大学特任助教松宮智央氏以下、大学 院生諸君の協力を得た。ここに記して謝意を表す。

\section{参考文献}

1) INLAND STEEL BUILDING, GA 10 Contemporary Architecture OFFICE 1, p.26, 2007.10

2) 田中 智三, 田㴊 基嗣, 田中 剛, 難波 尚: 梁偏心接合形式の角形鋼管柱 ・梁接合部パネルに関する研究 その 1. 有限要素解析による予備検討, 日 本建築学会大会学術講演梗概集 C-1, pp.551-552, 1999.7

3) 増田 浩志, 田中 淳夫, 石丸亮, 平井弘毅, 笹治 峻: ダイアフラム内 蔵角形鋼管柱と側梁の鉛直スチフナを用いた接合部に関する研究，日本建 築学会構造系論文集 第 534 号, pp.167-174, 2000.8

4) 押田光弘, 一戸康生, 石橋久義, 齋藤啓一, 福元敏之, 立花正彦, 森田耕 次 : 鉄骨偏心梁の取り付く通しダイアフラム形式・角形 CFT 柱接合部の 力学的性状, 鋼構造論文集第 12 巻第 47 号, pp.23-32,2005.9

5) 劉 翠平, 田川 浩: $\mathrm{H}$ 形断面柱梁偏心接合部のパネル耐力, 日本建築学 会構造系論文集 第 74 巻第 636 号, pp.375-384, 2009.2

6) S. P. Timoshenko and J. N. Goodier: Theory of Elasticity, Third Edition, McGraw-Hill, 1982

7) 加藤 勉 : 鉄骨構造, 彰国社, 1971

8) (独)建築研究所, (社) 日本鉄鋼連盟, 鋼構造建築物の構造性能評価試験法に 関する研究委員会報告書, 2002.4 